\title{
Effect of Site Specific Nutrient Management on the Performance of Bt Cotton (Gossypium hirsutum L.) and Nutrient Dynamics
}

\author{
Vinayak Hosamani $^{1 *}$, B.M. Chittapur ${ }^{2}$, Mallikarjun ${ }^{3}$, A.S. Halepyati ${ }^{4}$, \\ Satyanarayana Rao ${ }^{5}$, M.B. Patil ${ }^{6}$, N.L. Rajesh $^{7}$ and Venkatesh Hosamani ${ }^{8}$
}

${ }^{1}$ P2 BSF, Nagenahally, Kunigal, Central Silk Board, Bangalore/ UAS, Raichur, Karnataka, India

${ }^{2}$ Directorate of Extension, University of Agricultural Sciences, Raichur, Karnataka, India

${ }^{3} e$-SAP, Project, University of Agricultural Sciences, Raichur, Karnataka, India

${ }^{4}$ University of Agricultural Sciences, Raichur, Karnataka, India

${ }^{5}$ Research Institute on Organic Farming, MARS, UAS, Raichur, Karnataka, India

\author{
${ }^{6}$ AEEC, Koppal, UAS, Raichur, Karnataka, India \\ ${ }^{7}$ (SS\&AC), COA, UAS, Raichur, Karnataka, India \\ ${ }^{8}$ Entomology, COH, Munirabad-Koppal, Karnataka, India \\ *Corresponding author
}

\section{A B S T R A C T}

\section{Keywords}

Bt cotton, SSNM and RDF, Cotton, Nutrient use efficiency

Article Info

Accepted:

22 July 2018

Available Online:

10 August 2018
The field experiment on cotton productivity and leaf reddening as influenced by nutrition management for targeted yield was conducted during growing seasons of 2014-15 and 2015-16 at College of Agriculture Farm, Raichur, Karnataka on medium deep black soil under irrigation. Three yield targets $\left(3,4\right.$ and $5 \mathrm{t}$ kapas yield $\left.\mathrm{ha}^{-1}\right)$ based site specific nutrient management (SSNM) along with four leaf reddening management (LRM) treatments (S1 - Vermicompost @ $2.5 \mathrm{tha}^{-1}$ in seed line, $\mathrm{S} 2-\mathrm{S} 1+\mathrm{MgSO}_{4} 10 \mathrm{~kg} \mathrm{~h}^{-1}$ in seed line, $\mathrm{S} 3-\mathrm{S} 1+\mathrm{MgSO}_{4} 25 \mathrm{~kg} \mathrm{ha}^{-1}$ in seed line, and S4 - $\mathrm{MgSO}_{4} 25 \mathrm{~kg} \mathrm{ha}^{-1}$ in seed line + foliar nutrition of $1 \% \mathrm{MgSO}_{4}+19: 19: 19+1 \% \mathrm{KNO}_{3}$ trice during flowering, boll development and boll bursting stages) besides recommended control were tested using RCBD. Plloed data on the experimental results revealed that SSNM for $5 \mathrm{tha}^{-1}$ yield target and supplementary nutrition of $\mathrm{MgSO}_{4}$ both to soil and to foliage and foliar application of major nutrients (19:19:19 and $\mathrm{KNO}_{3}$ ) (S4) recorded significantly higher NUE (14.30 on pooled basis), PUE (60.81 on pooled basis), KUE (31.37 on pooled basis), had higher IPUE (115.0 on pooled basis) and IKUE values ( 24.6 to 24.7 on pooled basis).

\section{Introduction}

Cotton (Gossypium spp), the king of fibres or white gold, enjoys a predominant position amongst cash crops in India and world as well. In India, cotton is grown on an area of $12.8 \mathrm{~m}$ ha with a production of $38 \mathrm{~m}$ bales and productivity of $504 \mathrm{~kg}$ lint per ha during 201415 (CCI) (Anon., 2014). In Karnataka, cotton is grown on an area of $8.69 \mathrm{~m}$ ha with production of $0.34 \mathrm{~m}$ tonnes and productivity of $630 \mathrm{~kg}$ per ha in 2014-15 according to 
Ministry of Textiles, Govt. of India. (ON512, ON939) (Anon., 2014). The productivity, however, is much lower than the world average of $766 \mathrm{~kg}$ per ha. Nevertheless, the resurgence of cotton, the white gold of rural India can help resurrect the spirit of the Gandhian 'spinning wheel' and the glory of the cotton and textile sectors in the country (Choudhary and Gaur, 2015). India has made remarkable progress in food security, poverty reduction and per capita income since the green revolution. However, of late the growth rate in agriculture has not kept pace with the phenomenal growth rate in industrial and service sectors.

Diminishing and degrading natural resources make this task ever difficult. Soil fertility and its evaluation is one area which needs immediate attention since it is now an established fact that an arrest in the productivity of several crops, apart from others, is due to the ever decreasing soil fertility on one hand and an imbalanced application of plant nutrients on the other. Despite being the second largest user of fertilizers, the per hectare fertilizer use in India is still low and imbalanced. The NPK use ratio in 2009-10 was 4.3:2.0:1 which has widened to 6.7:3.1:1 in 2011-12 and it has been further distorted in 2012-13 against the desired ratio of 4:2:1 (Satish Chander, 2013). The use of external inputs till now has driven the crop productivity gains in India but in future, there is need to focus on precision and knowledge intensive technologies and adoption of the same on individual farms or fields from the point of productivity, economics, natural resource sustainability and safe environment. In this context, SiteSpecific Nutrient Management (SSNM) approach is one such option which focuses on balanced and crop need-based nutrient application (Johnston et al., 2009) helps to increase the nutrient use efficiencies and productivity of the Bt cotton.

\section{Materials and Methods}

Experiment was carried out at Agricultural College Farm, University of Agricultural Sciences, Raichur, and Karnataka during growing seasons of 2014-15 and 2015-16 under irrigation. The experiment consisted of three main plot treatments (SSNM based nutrition for 3, 4 and $5 \mathrm{t} \mathrm{ha}^{-1}$ seed cotton - M13) and four sub plot treatments (nutrient supplementation to manage leaf reddening malady (LRM): S1 - Vermicompost @ $2.5 \mathrm{t}$ $\mathrm{ha}^{-1}$ in seed line, $\mathrm{S} 2-\mathrm{S} 1+\mathrm{MgSO}_{4} 10 \mathrm{~kg} \mathrm{ha}^{-1}$ in seed line, $\mathrm{S} 3-\mathrm{S} 1+\mathrm{MgSO}_{4} 25 \mathrm{~kg} \mathrm{ha}^{-1}$ in seed line and $\mathrm{S} 4-\mathrm{MgSO}_{4} 25 \mathrm{~kg} \mathrm{ha}^{-1}$ in seed line + foliar nutrition of 1\% $\mathrm{MgSO}_{4}+19: 19: 19$ $+1 \% \mathrm{KNO}_{3}$ thrice during flowering, boll development and boll bursting stages) alongwith recommended fertilizer practice (RDF) as outside control for comparison ( $3 \mathrm{x}$ $4+1)$. For the yield targets fertilizers were applied based on the soil test and crop requirement as per SSNM (IPNI). In control the recommended doses of fertilizers were applied (150 N, 75 P2O5 and $\left.75 \mathrm{~K} \mathrm{~kg} \mathrm{ha}^{-1}\right)$.

Nitrogen, phosphorus and potassium use efficiency were calculated by using the following formula as given by Peng et al., (1996).

NUE/ $\quad \begin{gathered}\text { PUE/ } \\ \text { Cotton yield (kg/ha) }\end{gathered}$

Internal nitrogen, phosphorus and potassium use efficiencies were calculated by using the following formula as given by Peng et al., (1996).

\section{INUE/ IPUE/ IKUE = \\ Total Nitrogen / phosphorus/ potassium uptake (kg/ha)}

The data taken from the experiment at different growth stages were subjected to statistical analysis (Gomez and Gomez, 1984) 
at $\mathrm{P}=0.05$ and means were compared using Duncan's Multiple Range Test (DMRT) using SPSS 16.0 version. Third order interactions were presented and discussed in the article.

\section{Results and Discussion}

Nitrogen use efficiency (NUE) values were small and overall variations were marginal but significant. Significant variations in NUE were observed due to SSNM based nutrition during both the years and on pooled basis (Table 2). Yield target of $3 \mathrm{t} \mathrm{ha}^{-1}\left(\mathrm{M}_{1}\right)$ recorded marginally higher NUE (13.98 on pooled basis) during both the years of experimentation and in the pooled mean. Decreased NUE was evident with increase in yield target, recording the lowest NUE (12.71 on pooled basis) with the yield target of $5 \mathrm{t}$ $\mathrm{ha}^{-1}\left(\mathrm{M}_{3}\right)$; while $4 \mathrm{t} \mathrm{ha}^{-1}\left(\mathrm{M}_{2}\right)$ target fell in between and was comparable to lower yield targets on yearly basis. Additional application of nutrition for management of leaf reddening also resulted in significant variation wherein significantly higher NUE (13.65 on pooled basis) during both the years and in pooled mean was recorded with the application of 25 $\mathrm{kg} \mathrm{ha}{ }^{-1} \mathrm{MgSO}_{4}$ to soil along with foliar nutrition of 1\% each of $\mathrm{MgSO}_{4}, 19: 19: 19$ and $\mathrm{KNO}_{3}\left(\mathrm{~S}_{4}\right)$; other treatments were midway or overlying in their effect, while application of vermicompost alone $\left(\mathrm{S}_{1}\right)$ had lower NUE (13.18 on pooled basis) among all during both individual years and in pooled mean. Interaction effects between SSNM targets and LRM practices were significant, in that, treatment combination of SSNM with $3 \mathrm{t} \mathrm{ha}^{-1}$ yield target and application of $\mathrm{MgSO}_{4} @ 25$ $\mathrm{kg} \mathrm{ha}^{-1}$ along with foliar nutrition of $1 \%$ each of $\mathrm{MgSO}_{4}, 19: 19: 19$ and $\mathrm{KNO}_{3}$ (thrice) $\left(\mathrm{M}_{1} \mathrm{~S}_{4}\right)$ resulted in higher NUE (14.30 on pooled basis) among all treatment combinations and with higher yield target irrespective of LRM practices the values decreased. Significantly, lower NUE (12.52 on pooled basis) among all was observed with $5 \mathrm{t} \mathrm{ha}^{-1}$ along with application of vermicompost alone $\left(\mathrm{M}_{3} \mathrm{~S}_{1}\right)$ while $\mathrm{M}_{3} \mathrm{~S}_{2}$ and $\mathrm{M}_{3} \mathrm{~S}_{3}$ were at par with the former combination. Interestingly, all the combinations comprising SSNM based nutrition and supplemental nutrition for leaf reddening malady control recorded lower NUE than control (18.77 on pooled basis) during both the years and on pooled basis as well.

Phosphorus use efficiency values (PUE) were higher than NUE values, and overall variations were significant during both the years and on pooled basis (Table 2). Yield target of $3 \mathrm{t} \mathrm{ha}^{-1}\left(\mathrm{M}_{1}\right)$ recorded significantly higher PUE (59.43 on pooled basis) among all which decreased with increase in yield target reaching the lowest (53.94 on pooled basis) with the yield target of $5 \mathrm{t} \mathrm{ha}^{-1}\left(\mathrm{M}_{3}\right)$; while $4 \mathrm{t}$ ha-1 $\left(\mathrm{M}_{2}\right)$ target fared in between. Additional application of nutrition for management of leaf reddening also resulted in significant variation wherein significantly higher PUE (57.99 on pooled basis) during both the years and in pooled mean was recorded with the application of $25 \mathrm{~kg} \mathrm{ha}^{-1} \mathrm{MgSO}_{4}$ to soil along with foliar nutrition of $1 \%$ each of $\mathrm{MgSO}_{4}$, 19:19:19 and $\mathrm{KNO}_{3}\left(\mathrm{~S}_{4}\right)$; other treatments were midway or overlying in their effect while application of vermicompost alone $\left(S_{1}\right)$ had lower PUE (55.99 on pooled basis) among all during both individual years and in pooled mean. Interaction effects between SSNM targets and LRM practices were significant, in that, treatment combination of SSNM with $3 \mathrm{t}$ $\mathrm{ha}^{-1}$ yield target and application of $\mathrm{MgSO} 4$ @ $25 \mathrm{~kg} \mathrm{ha}^{-1}$ along with foliar nutrition of $1 \%$ each of $\mathrm{MgSO}_{4}, 19: 19: 19$ and $\mathrm{KNO}_{3}$ (thrice) $\left(\mathrm{M}_{1} \mathrm{~S}_{4}\right)$ resulted in higher PUE (60.81 on pooled basis) among all treatment combinations, and with higher yield target irrespective of LRM practices the values decreased. Significantly lower use efficiency (53.14 on pooled basis) among all was observed with $5 \mathrm{t} \mathrm{ha}^{-1}$ along with application of vermicompost alone $\left(\mathrm{M}_{3} \mathrm{~S}_{1}\right)$ while $\mathrm{M}_{3} \mathrm{~S}_{2}$ and 
$\mathrm{M}_{3} \mathrm{~S}_{3}$ were at par with the former combination during both years. Again unlike NUE, all the combinations comprising SSNM based nutrition and supplemental nutrition for leaf reddening control recorded significantly higher PUE than control with recommended nutritional package (37.54 on pooled basis) during both the years and on pooled basis as well.

Data on potassium use efficiency (KUE) were in similar range as that of NUE, and KUE varied marginally, however, the variations were significant due to SSNM based yield targets, LRM practices and their interactions during both the years and on pooled basis (Table 2). Among SSNM based yield targets, significantly higher KUE (30.66 on pooled basis) was observed with yield target of $3 \mathrm{t}$ $\mathrm{ha}^{-1}\left(\mathrm{M}_{1}\right)$, while lower KUE (27.82 on pooled basis) was recorded with yield target of $5 \mathrm{t}$ ha $^{-1}\left(M_{3}\right)$; $4 \mathrm{t} \mathrm{ha}^{-1}\left(\mathrm{M}_{2}\right)$ had intermediate value. Among LRM practices, significantly higher KUE (29.91 on pooled basis) during both years of experimentation and in pooled mean was recorded with the application of $25 \mathrm{~kg}$ $\mathrm{MgSO}_{4}$ in seed line along with foliar nutrition of $1 \%$ each of $\mathrm{MgSO}_{4}, 19: 19: 19$ and $\mathrm{KNO}_{3}$ (thrice) $\left(\mathrm{S}_{4}\right)$. Rest of the treatments were intermediate or overlapping, while application of vermicompost alone $\left(S_{1}\right)$ as an organic nutrient supplementation registered significantly lower KUE (28.88 on pooled basis) among all. Similarly, KUE values due to the interaction effect of SSNM and nutrient supplementation for leaf reddening varied significantly wherein $3 \mathrm{t} \mathrm{ha}^{-1}$ yield target particularly in combination with application of $25 \mathrm{~kg} \mathrm{ha}^{-1} \mathrm{MgSO}_{4}$ in seed line along with foliar nutrition of 1\% $\mathrm{MgSO}_{4}, 19: 19: 19$ and $\mathrm{KNO}_{3}\left(\mathrm{M}_{1} \mathrm{~S}_{4}\right)$ resulted in higher KUE (31.37 on pooled basis); the KUE values decreased with increasing yield target and reached the minimum (27.41 on pooled basis) with $5 \mathrm{t} \mathrm{ha}^{-1}$ yield target in combination with vermicompost $\left(\mathrm{M}_{3} \mathrm{~S}_{1}\right)$, and $\mathrm{M}_{3} \mathrm{~S}_{4}$ differed significantly from it only in pooled means. Like NUE, KUE values with SSNM based nutrition in combination with supplemental nutrition for leaf reddening malady control were significantly lower than control (37.54 on pooled basis) during both the years and on pooled basis as well.

Internal nitrogen use efficiency (INUE) did not reveal significant variations due to SSNM based yield targets, LRM practices or their combinations during the years of experimentation and on pooled basis (Table. 3 ). The INUE values ranged from 23.7 to 24.1 due to SSNM levels, 23.8 to 23.9 due to LRM practices and 23.7 to 24.1 due to their interactions while control had 23.9 per cent.

Table.1 Soil test value, ratings, nutrient requirement to achieve the target and adjusted nutrients during 2014-15 and 2015-16

\begin{tabular}{|c|c|c|c|c|}
\hline \multirow{2}{*}{$\begin{array}{c}\text { Yield } \\
\text { Targets }\end{array}$} & \multicolumn{2}{|c|}{ Soil test value $\left(\mathrm{N}: \mathrm{P}_{2} \mathrm{O}_{5}: \mathrm{K}_{2} \mathrm{O} \mathrm{kg} \mathrm{ha}{ }^{-1}\right)$} & \multirow{2}{*}{$\begin{array}{c}\text { Nutrient } \\
\text { requirement } \\
\left(\mathrm{N}: \mathrm{P}_{2} \mathrm{O}_{5}: \mathrm{K}_{2} \mathrm{O} \mathrm{kg}\right. \\
\left.\text { ha }^{-1}\right)\end{array}$} & \multirow{2}{*}{$\begin{array}{c}\text { Final applied } \\
\left(\mathrm{N}: \mathrm{P}_{2} \mathrm{O}_{5}: \mathrm{K}_{2} \mathrm{O}\right. \\
\left.\mathrm{kg} \mathrm{ha}^{-1}\right)\end{array}$} \\
\hline & 2014-15 & 2015-16 & & \\
\hline 3 t ha $^{-1}$ & $168: 72: 184$ & 198:74:208 & $192: 84: 114$ & $240: 63: 114$ \\
\hline $4 \mathrm{t} \mathrm{ha}^{-1}$ & $168: 72: 184$ & $198: 74: 208$ & $256: 112: 152$ & $316: 84: 152$ \\
\hline $5 \mathrm{t} \mathrm{ha}^{-1}$ & $168: 72: 184$ & 198:74:208 & 320:140:190 & $400: 105: 190$ \\
\hline
\end{tabular}


Table.2 Nitrogen, phosphorous, and potassium use efficiency (\%) of cotton as influenced by SSNM based yield targets and nutrition for leaf reddening management ((pooled two years))

\begin{tabular}{|c|c|c|c|c|}
\hline Treatment & NUE & PUE & KUE & Seed cotton yield kg/ ha \\
\hline \multicolumn{5}{|l|}{ Main plots } \\
\hline $\mathrm{M}_{1}$ & $13.98^{\mathrm{a}}$ & $59.43^{\mathrm{a}}$ & $30.66^{\mathrm{a}}$ & $3482^{c}$ \\
\hline $\mathbf{M}_{2}$ & $13.55^{\mathrm{b}}$ & $57.53^{\mathrm{b}}$ & $29.67^{b}$ & $4494^{b}$ \\
\hline $\mathbf{M}_{3}$ & $12.71^{\mathrm{c}}$ & $53.94^{\mathrm{c}}$ & $27.82^{c}$ & $5246^{\mathrm{a}}$ \\
\hline S.Em土 & 0.21 & 0.45 & 0.10 & 76.9 \\
\hline \multicolumn{5}{|l|}{ Sub plots } \\
\hline $\mathbf{S}_{1}$ & $13.18^{c}$ & $55.99^{d}$ & $28.88^{c}$ & $4318^{b}$ \\
\hline $\mathbf{S}_{2}$ & $13.35^{\mathrm{bc}}$ & $56.69^{c}$ & $29.24^{\mathrm{bc}}$ & $4384^{\mathrm{a}}$ \\
\hline $\mathbf{S}_{\mathbf{3}}$ & $13.47^{\text {ba }}$ & $57.21^{b}$ & $29.51^{\text {ba }}$ & $4434^{\mathrm{a}}$ \\
\hline $\mathrm{S}_{4}$ & $13.65^{\mathrm{a}}$ & $57.99^{\mathrm{a}}$ & $29.91^{\mathrm{a}}$ & $4495^{\mathrm{a}}$ \\
\hline S.Em士 & 0.19 & 0.38 & 0.10 & 40.6 \\
\hline \multicolumn{5}{|l|}{$\mathbf{M} \times \mathbf{S}$} \\
\hline $\mathbf{M}_{1} \mathbf{S}_{1}$ & $13.69^{\mathrm{dc}}$ & $58.21^{\mathrm{dc}}$ & $30.02^{\mathrm{dc}}$ & $3401^{\mathrm{i}}$ \\
\hline $\mathbf{M}_{1} \mathbf{S}_{2}$ & $13.87^{\mathrm{bc}}$ & $58.96^{\mathrm{bc}}$ & $30.41^{b c}$ & $3452^{\text {hi }}$ \\
\hline $\mathbf{M}_{1} \mathbf{S}_{3}$ & $14.06^{\mathrm{ba}}$ & $59.76^{\text {ba }}$ & $30.82^{\text {ba }}$ & $3509^{\text {hg }}$ \\
\hline $\mathbf{M}_{1} \mathbf{S}_{4}$ & $14.30^{\mathrm{a}}$ & $60.81^{\mathrm{a}}$ & $31.37^{\mathrm{a}}$ & $3568^{\mathrm{g}}$ \\
\hline $\mathbf{M}_{2} \mathbf{S}_{1}$ & $13.34^{\mathrm{d}}$ & $56.63^{e}$ & $29.21^{d}$ & $4407^{\mathrm{f}}$ \\
\hline $\mathbf{M}_{2} \mathbf{S}_{2}$ & $13.52^{\text {bdc }}$ & $57.40^{\mathrm{de}}$ & $29.60^{\mathrm{dc}}$ & $4487^{\mathrm{e}}$ \\
\hline $\mathrm{M}_{2} \mathrm{~S}_{3}$ & $13.60^{\text {bdc }}$ & $57.73^{\mathrm{de}}$ & $29.78^{\mathrm{dc}}$ & $4517^{\text {ed }}$ \\
\hline $\mathbf{M}_{2} \mathbf{S}_{4}$ & $13.75^{\mathrm{bac}}$ & $58.37^{\text {de }}$ & $30.11^{b c}$ & $4568^{d}$ \\
\hline $\mathbf{M}_{3} \mathbf{S}_{1}$ & $12.52^{f}$ & $53.14^{\mathrm{h}}$ & $27.41^{\mathrm{f}}$ & $5148^{c}$ \\
\hline $\mathbf{M}_{3} \mathbf{S}_{2}$ & $12.65^{\mathrm{fe}}$ & $53.70^{\mathrm{gh}}$ & $27.70^{\mathrm{fe}}$ & $5212^{\mathrm{cb}}$ \\
\hline $\mathrm{M}_{3} \mathrm{~S}_{3}$ & $12.75^{\mathrm{fe}}$ & $54.13^{\mathrm{gf}}$ & $27.92^{\text {fe }}$ & $5275^{b}$ \\
\hline $\mathbf{M}_{3} \mathbf{S}_{4}$ & $12.91^{\mathrm{e}}$ & $54.79^{f}$ & $28.26^{\mathrm{e}}$ & $5349^{a}$ \\
\hline S.Em土 & 0.34 & 0.67 & 0.18 & 86.9 \\
\hline Control & 18.77 & 37.54 & 37.54 & 2836 \\
\hline S.Em \pm & 0.32 & 1.29 & 1.31 & 162.6 \\
\hline C.D. 0.05 & 0.93 & 3.77 & 3.83 & 474.5 \\
\hline
\end{tabular}

*means with same letters do not differ significantly under DMRT

Note: SSNM- Site Specific Nutrient Management

Main treatments: Yield Target (M)

$\mathrm{M}_{1}$ - SSNM for targeted yield of 3 tha $^{-1}$

$\mathrm{M}_{2}$ - SSNM for targeted yield of 4 tha $^{-1}$

$\mathrm{M}_{3}$ - SSNM for targeted yield of 5 tha $^{-1}$

Control-RDF with recommended practice
Sub treatments: Leaf reddening management (S)

$\mathbf{S}_{\mathbf{1}^{-}}$Vermicompost @ 2.5 tha $^{-1}$ in seed line

$\mathbf{S}_{2^{-}} \mathrm{S}_{1}+\mathrm{MgSO}_{4} 10 \mathrm{kgha}^{-1}$ in seed line

$\mathrm{S}_{3^{-}} \mathrm{S}_{1}+\mathrm{MgSO}_{4} 25 \mathrm{kgha}^{-1}$ in seed line

$\mathbf{S}_{4^{-}} \mathrm{MgSO}_{4} 25 \mathrm{~kg} \mathrm{ha}^{-1}$ in seed line + foliar nutrition of $1 \%$

$\mathrm{MgSO}_{4}+19: 19: 19+1 \% \mathrm{KNO}_{3}$ (thrice each) 
Table.3 Internal Nitrogen, phosphorous, and potassium use efficiency (\%) of cotton as influenced by SSNM based yield targets and nutrition for leaf reddening management (pooled two years)

\begin{tabular}{|c|c|c|c|}
\hline Treatment & NUE & PUE & KUE \\
\hline \multicolumn{4}{|l|}{ Main plots } \\
\hline $\mathrm{M}_{1}$ & $24.1^{\mathrm{a}}$ & $112.2^{\mathrm{b}}$ & $23.5^{\mathrm{b}}$ \\
\hline $\mathbf{M}_{2}$ & $23.7^{\mathrm{a}}$ & $113.2^{\mathrm{ba}}$ & $22.9^{\mathrm{ba}}$ \\
\hline $\mathbf{M}$ & $23.7^{\mathrm{a}}$ & $115.0^{\mathrm{a}}$ & $24.6^{\mathrm{a}}$ \\
\hline S.Em \pm & 0.25 & 1.5 & 0.7 \\
\hline \multicolumn{4}{|l|}{ Sub plots } \\
\hline$S_{1}$ & $23.9^{\mathrm{a}}$ & $113.0^{\mathrm{a}}$ & $23.8^{\mathrm{a}}$ \\
\hline$S_{2}$ & $23.8^{\mathrm{a}}$ & $113.1^{\mathrm{a}}$ & $23.7^{\mathrm{a}}$ \\
\hline$S_{3}$ & $23.8^{\mathrm{a}}$ & $113.2^{\mathrm{a}}$ & $23.7^{\mathrm{a}}$ \\
\hline$S_{4}$ & $23.8^{\mathrm{a}}$ & $113.3^{\mathrm{a}}$ & $23.7^{\mathrm{a}}$ \\
\hline S.Em \pm & 0.29 & 1.5 & 1.0 \\
\hline \multicolumn{4}{|l|}{$\mathbf{M} \times \mathrm{S}$} \\
\hline $\mathbf{M}_{1} \mathbf{S}_{1}$ & $24.1^{\mathrm{a}}$ & $111.1^{\mathrm{c}}$ & $23.6^{\mathrm{bcd}}$ \\
\hline $\mathbf{M}_{1} \mathbf{S}_{2}$ & $24.1^{\mathrm{a}}$ & $111.2^{\mathrm{c}}$ & $23.6^{\text {bcd }}$ \\
\hline $\mathbf{M}_{1} \mathbf{S}_{3}$ & $24.1^{\mathrm{a}}$ & $111.3^{\mathrm{c}}$ & $23.5^{\mathrm{bc}}$ \\
\hline $\mathbf{M}_{1} \mathbf{S}_{4}$ & $24.1^{\mathrm{a}}$ & $111.4^{c}$ & $23.5^{\mathrm{bc}}$ \\
\hline $\mathbf{M}_{2} \mathbf{S}_{1}$ & $23.7^{\mathrm{a}}$ & $113.1^{\mathrm{b}}$ & $23.0^{\mathrm{d}}$ \\
\hline $\mathbf{M}_{2} \mathbf{S}_{2}$ & $23.7^{\mathrm{a}}$ & $113.2^{b}$ & $22.9^{\text {cd }}$ \\
\hline $\mathbf{M}_{2} \mathbf{S}_{3}$ & $23.7^{\mathrm{a}}$ & $113.2^{\mathrm{b}}$ & $22.8^{\mathrm{cd}}$ \\
\hline $\mathbf{M}_{2} \mathbf{S}_{4}$ & $23.7^{\mathrm{a}}$ & $113.4^{\mathrm{b}}$ & $22.9^{\mathrm{cd}}$ \\
\hline $\mathbf{M}_{3} \mathbf{S}_{1}$ & $23.7^{\mathrm{a}}$ & $115.0^{\mathrm{a}}$ & $24.7^{\mathrm{a}}$ \\
\hline $\mathbf{M}_{3} \mathbf{S}_{2}$ & $23.7^{\mathrm{a}}$ & $115.0^{\mathrm{a}}$ & $24.7^{\mathrm{a}}$ \\
\hline $\mathbf{M}_{3} \mathbf{S}_{3}$ & $23.7^{\mathrm{a}}$ & $115.1^{\mathrm{a}}$ & $24.6^{\mathrm{a}}$ \\
\hline $\mathbf{M}_{3} \mathbf{S}_{4}$ & $23.7^{\mathrm{a}}$ & $115.1^{\mathrm{a}}$ & $24.6^{\mathrm{a}}$ \\
\hline S.Em \pm & 0.50 & 2.64 & 1.7 \\
\hline Control & 23.9 & 107.2 & 23.7 \\
\hline S.Em士 & 1.25 & 1.61 & 1.6 \\
\hline C.D. 0.05 & NS & NS & NS \\
\hline
\end{tabular}

*means with same letters do not differ significantly under DMRT

Note: SSNM- Site Specific Nutrient Management

Main treatments: Yield Target $(M) \quad$ Sub treatments: Leaf reddening management (S)

$\mathrm{M}_{1}$ - SSNM for targeted yield of 3 tha $^{-1}$

$\mathrm{M}_{2}$ - SSNM for targeted yield of 4 tha $^{-1}$

$\mathrm{M}_{3^{-}}$SSNM for targeted yield of 5 tha $^{-1}$

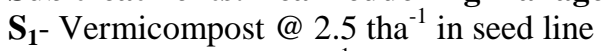

$\mathbf{S}_{2}-\mathrm{S}_{1}+\mathrm{MgSO}_{4} 10 \mathrm{kgha}^{-1}$ in seed line

$\mathrm{S}_{3}-\mathrm{S}_{1}+\mathrm{MgSO}_{4} 25 \mathrm{kgha}^{-1}$ in seed line

$\mathbf{S}_{4}-\mathrm{MgSO}_{4} 25 \mathrm{~kg} \mathrm{ha}^{-1}$ in seed line + foliar nutrition of $1 \%$

Control-RDF with recommended practice

$\mathrm{MgSO}_{4}+19: 19: 19+1 \% \mathrm{KNO}_{3}$ (thrice each)

Unlike $\mathrm{N}$, internal phosphorus use efficiency (IPUE) differed marginally, however differences were significant due to SSNM based yield targets and their interaction with LRM practices (Table 3). Among the yield targets, $5 \mathrm{t} \mathrm{ha}^{-1}$ had higher IPUE (115.0 on 
pooled basis) during first year and on pooled basis. Among interactions, SSNM levels differed significantly and LRM practices were at par within each target; the values increased with increase in yield target recording maximum with $5 \mathrm{t} \mathrm{ha}^{-1}$ (115.0 to 115.1 on pooled basis), while yield target of $3 \mathrm{t} \mathrm{ha}^{-1}$ had significantly lower IPUE values (111.1 to 111.4 on pooled basis) during the year of experimentation and on pooled basis. Control registered lower IPUE (108.6, 105.9 and 107.2 $\mathrm{kg} \mathrm{ha}^{-1}$ during 2014-15 and 2015-16 and on pooled basis respectively).

Internal potassium use efficiency (IKUE) values were in the same range as that of INUE but the data behaved similarly as that of IPUE (Table 3). IKUE differed marginally, however, the differences were significant due to SSNM based yield targets and their interaction with LRM practices only. Among the yield targets, $5 \mathrm{t} \mathrm{ha}{ }^{-1}\left(\mathrm{M}_{3}\right)$ had significantly higher IKUE (24.6 on pooled basis) and it decreased with yield targets wherein $3 \mathrm{t} \mathrm{ha}^{-1}\left(\mathrm{M}_{1}\right)$ had significantly lower IKUE (23.5 on pooled basis). Among interactions, $5 \mathrm{t} \mathrm{ha}^{-1}$, LRM practices being on par, $\left(\mathrm{M}_{3} \mathrm{~S}_{1-4}\right)$ recorded significantly higher IKUE values (24.6 to 24.7 on pooled basis), other treatment combinations were at par and lower IKUE values (23.0 on pooled basis) among all were recorded with $4 \mathrm{t} \mathrm{ha}^{-1}$ yield target receiving only organic amendment in the form of vermicompost $\left(\mathrm{M}_{2} \mathrm{~S}_{1}\right)$ during all the years of study and on pooled basis. Differences between control (23.7 on pooled basis) and any of the treatment combinations were not significant.

SSNM with $3 \mathrm{t}^{-1}$ yield target and application of $\mathrm{MgSO}_{4} @ 25 \mathrm{~kg} \mathrm{ha}^{-1}$ along with foliar nutrition of $1 \%$ each of $\mathrm{MgSO}_{4}$, 19:19:19 and $\mathrm{KNO}_{3}$ resulted in higher NUE (14.30 on pooled basis), PUE (60.81 on pooled basis) and KUE (31.37 on pooled basis); and these efficiencies decreased with increasing yield target and reached the minimum $(12.52,53.14$ and 24.71 on pooled basis) with $5 \mathrm{t} \mathrm{ha}^{-1}$ yield target in combination with vermicompost $\left(\mathrm{M}_{3} \mathrm{~S}_{1}\right)$. Again, this is also on the expected line as higher the biomass, lower will be use efficiencies in spite of higher uptake due to dilution effect as the relative biomass production will be lesser with every additional dose of nutrient and this relation follows law of diminishing returns. Doberman and Fairhurst (2000) reported that SSNM improved the plant uptake of N, P and $\mathrm{K}$ by 10 to $20 \%$ and $\mathrm{N}$ use efficiency by $40 \%$. In fact, SSNM approach was developed to increase mineral fertilizer use efficiency and to achieve balanced plant nutrition (Doberman et al., 1999; Witt et al., 1999 and Doberman and Fairhurst, 2000).

\section{References}

Anonymous, 2014, Annual report. Cotton Advisory Board.

Ashok, S., Madhukar, K., Dadabhur, Y., Vanda, P. And Mayuray, M., 2004, Cotton Scenario in India. Curr. Sci., 87 (1): 8 .

Doberman, A. and Fairhurst, T., 2000, Rice: Nutrient disorders and nutrient management Potash and Phosphate Institute of Canada and Int. Rice Res. Inst., Singapore and Los Banos, pp. 191.

Doberman, A., Witt, C., Robert, P. C. and Larson, W. E., 1999, SSNM concept for irrigated system. Better Crops International.Vol.16, No. 1, 25: 1-7.

Johnston, A.M., H.S. Khurana, K. Majumdar, and T. Satyanarayana. 2009. JISSS 57(1):1-10.

Satish Chander, 2013, Adoption of fertilizer best management practices. Indian J. Fert., 9: 10-11.

Witt, C., Doberman, A., Abdilrachman, S., Gines, H. c., Ghanhuo, W., Nagarajan, R., Satawathanat, S., Tran Thuc Son, 
Pham Syton, Levantiem, Simbahan, G. and Olk, D. C., 1999, Internal nutrient efficiencies in irrigated low land rice of tropical and su $B t$ ropical Asia, Field Crops Res., 63: 115-138.

\section{How to cite this article:}

Vinayak Hosamani, B.M. Chittapur, Mallikarjun, A.S. Halepyati, Satyanarayana Rao, M.B. Patil, N.L. Rajesh and Venkatesh Hosamani. 2018. Effect of Site Specific Nutrient Management on the Performance of Bt Cotton (Gossypium hirsutum L.) and Nutrient Dynamics. Int.J.Curr.Microbiol.App.Sci. 7(08): 4082-4089. doi: https://doi.org/10.20546/ijcmas.2018.708.424 